\title{
Antidiabetic Activity of Extract and Fractions of Castanopsis costata Leaves on Alloxan-induced Diabetic Mice
}

\author{
Maulana Yusuf Alkandahri ${ }^{1 * *}$, Dani Sujana ${ }^{2}$, Dadang Muhammad Hasyim², Mareetha Zahra Shafirany ${ }^{3}$, Lela \\ Sulastri ${ }^{4}$, Maya Arfania' ${ }^{1}$ Dedy Frianto', Farhamzah ${ }^{1}$, Anggun Hari Kusumawati' ${ }^{1}$ Nia Yuniarsih'
}

Maulana Yusuf Alkandahri,**, Dani Sujana ${ }^{2}$, Dadang Muhammad Hasyim ${ }^{2}$, Mareetha Zahra Shafirany ${ }^{3}$, Lela Sulastri', Maya Arfania', Dedy Frianto', Farhamzah', Anggun Hari Kusumawati ${ }^{1}$, Nia Yuniarsih

'Faculty of Pharmacy, Buana Perjuangan Karawang University, Karawang, West Java, INDONESIA.

${ }^{2}$ Diploma Program of Pharmacy, Karsa Husada Garut College of Health Sciences, Garut, West Java, INDONESIA.

${ }^{3}$ Department of Pharmaceutical Biology,

School of Pharmacy Muhammadiyah

Cirebon, Cirebon, West Java, INDONESIA. ${ }^{4}$ Department of Pharmaceutics and

Pharmaceutical Technology, School of

Pharmacy Muhammadiyah Cirebon,

Cirebon, West Java, INDONESIA.

\section{Correspondence}

\section{Maulana Yusuf Alkandahri}

Faculty of Pharmacy, Buana Perjuangan Karawang University, Karawang, West

Java, INDONESIA.

E-mail: alkandahri@gmail.com

History

- Submission Date: 20-10-2021;

- Review completed: 11-11-2021;

- Accepted Date: 17-11-2021.

DOI : 10.5530/pj.2021.13.204

Article Available online

http://www.phcogj.com/v13/i6

Copyright

(C) 2021 Phcogj.Com. This is an open access article distributed under the terms of the Creative Commons Attribution 4.0 International license.

\section{ABSTRACT}

Background: In North Sumatra, Castanopsis costata is commonly used by traditional practitioners for the treatment of diabetes mellitus, however, no studies have been carried out to substantiate this practice. Therefore, this study aims to evaluate the anti-diabetic activity of extract and fractions of $C$. costata leaves in mice with alloxan-induced diabetes. Methods: Swiss albino mice with alloxan-induced diabetes, were acquired and subjected to the experimental evaluations. Subsequently, the fasting blood glucose levels of the diabetic mice groups treated with glibenclamid, extract and fractions, as well as the untreated group, were evaluated after two weeks of therapy. Results: Based on the results, the ethanolic extract of $C$. costata considerably reduced the mice's blood glucose levels in a dose-dependent manner, at dosages of $25,50,100$, and $200 \mathrm{mg} / \mathrm{kgBW}$ (\% DBGL: $21.10 \%, 46.36 \%, 58.94 \%$, and $60.93 \%$, respectively). In addition, the water fraction of $C$. costata leaves produced a greater reduction in blood glucose levels $(\%$ DBGL: $78.93 \%$ ), compared to the ethyl acetate and n-hexane fractions (\% DBGL: 67.06\% and 58.83\%), respectively. Meanwhile, treatment with the antidiabetic drug, glibenclamide $(5 \mathrm{mg} / \mathrm{kgBW})$ produced a $50.75 \%$ reduction in blood glucose levels. Conclusion: Based on the findings, the extract and fractions of C. costata leaves were concluded to exhibit significant anti-diabetic activity. This supported the claim that traditional practitioners in North Sumatra use the plant extract for diabetes treatment.

Key words: Castanopsis costata, Antidiabetic activity, Diabetes mellitus, North Sumatra.

\section{INTRODUCTION}

Diabetes mellitus is one of the world's most prevalent diseases and is characterized by a variety of causes that impair insulin production and/or activity, resulting in a loss of glucose homeostasis, as well as associated metabolic abnormalities of carbohydrate, fat, and protein. ${ }^{1-2}$ According to the International Diabetes Federation (IDF), increased blood glucose is the world's thirdleading risk factor for early death, after high blood pressure and cigarette use. ${ }^{2}$ Therefore, diabetes mellitus has become a major cause of illness and mortality, globally, with the number of cases estimated to be 642 million by 2040, the majority of whom live in low- and middle-income nations. ${ }^{3}$ Despite the availability of natural and synthetic numerous anti-diabetic medicines on the market, the condition remains a significant concern. ${ }^{4}$ Currently, the commonly used medicines for diabetes treatment are limited by several factors, including limited effectiveness, excessive cost, and various adverse effects. ${ }^{5}$ Alternatively, medicinal herbs with purported anti-diabetic properties are often used, particularly in underdeveloped nations. In comparison to traditional medications, these plants provide numerous advantages, including cost-effectiveness, ease of accessibility, broad cultural acceptance, and lesser side effects. ${ }^{6}$ A study by Piero et al., highlighted over 1,200 species of medicinal plants used by ethnic groups worldwide as traditional anti-diabetic medicines. ${ }^{4}$ These traditional medicines are believed to contain active ingredients with anti-diabetic activity, although the geographic conditions, climate, and extraction techniques used are also believed to have a possible influence on the potency. ${ }^{7-8}$

Indonesia has the world's country second largest forest biodiversity, with 28,000 plant species, of which 2,500 species, including Castanopsis costata, commonly known as "Cep-cepan", are used as medicine. ${ }^{9-10}$ C. costata belongs to the Fagaceae family and has been known to exhibit therapeutic activities, for instance, anti-fever, digestive issue alleviation, and analgesic properties. ${ }^{11}$ According to previous studies, C. costata exhibits numerous biological properties, including antioxidant activity, ${ }^{12}$ antiinflammatory activity, ${ }^{13}$ and antimalaria activity. ${ }^{10}$ Furthermore, in North Sumatra, the plant is frequently used to treat diabetes, however, there are no studies confirming this practice. Therefore, this study aims to evaluate the anti-diabetic activity of the extract and fractions of $C$. costata leaves.

\section{MATERIALS AND METHODS}

\section{Plant material collection and preparation}

About $10 \mathrm{~kg}$ of fresh C. costata leaves were collected in Pancur Batu Districts, North Sumatra, and transported to the Central Laboratory, Buana Perjuangan Karawang University for cleaning, air drying, milling, and extraction. The Herbarium Unit of the Department of Biology, Faculty of Mathematics and Science, Universitas Padjadjaran later recognized the plant as C. costata (Code: 219/HB/04/2017).

\section{Reagents and instruments}

This study induced diabetes in Swiss albino mice using alloxan monohydrate (Sigma Chemical 
Company, USA), while glibenclamide (PT Indofarma Tbk, Indonesia) was used as a conventional hypoglycemic agent. In addition, the plant components were extracted using ethanol (EMSURE ${ }^{\oplus}$ ACS Merck, Darmstadt, Germany), and the solvents were evaporated using a BUCHI Rotavapor ${ }^{\circledR}$ R-100 (PT. BUCHI Tangerang, Indonesia), while the blood glucose levels were determined using a Sinocare Safe-Accu Chek Glucometer (Sinocare Healthcare, Indonesia).

\section{Extraction and fractionation of $C$. costata}

About $1 \mathrm{~kg}$ of C. costata leaf powder was macerated in $70 \%$ ethanol for 72 hours to obtain a liquid extract. The liquid extract was then concentrated using a rotary evaporator at $50^{\circ} \mathrm{C}$ to reach a concentration of about $15.00 \%$ (fixed weights of the extracts were divided by simplicia weights multiplied by $100 \%$ ) and diluted in distilled water to create varied dosages as required. Subsequently, the ethanolic extract of C. costata leaves was diluted in a 1:3 combination of ethanol and water and about $100 \mathrm{~g}$ of the extract was separated by liquid-liquid partitioning using ethyl acetate (EA) $(4 \times 150 \mathrm{ml})$ and $n$-hexane $(4 \mathrm{x}$ $150 \mathrm{ml})$, to obtain 3 fractions: n-hexane ( $30.20 \mathrm{~g}, 30.20 \%)$, ethyl acetate (EA) $(43.00 \mathrm{~g}, 43.00 \%)$, and water (26.80 g, 26.80\%).

\section{Experimental animals}

A total of 36 adult male Swiss albino mice aged 2-3 months old with the body weights of 25-30 g, were obtained from the Animal House, School of Pharmacy, Institut Teknologi Bandung, and housed under normal conditions with 12 hour-12 hour light-dark cycles. The mice were caged in groups of four, with free access to food, as well as water, then moved to the laboratory 7 days before the clinical studies acclimate to the new habitat. This study protocol was approved by the Faculty of Medicine Ethics Committee, Universitas Padjadjaran, Indonesia (No. 359/UN6.KEP/EC/2021).

\section{Anti-diabetic assay}

For this assay, male Swiss albino mice were subjected for fasting throughout 12-14 hours overnigh, then their weight and fasting blood glucose levels were determined using a glucometer. Only mice with a fasting blood glucose level above $200 \mathrm{mg} / \mathrm{dl}$ were included in the study. ${ }^{14}$ To induce diabetes, each mouse was administered a single intraperitoneal injection of freshly prepared alloxan monohydrate solution $(150 \mathrm{mg} / \mathrm{kgBW}$ ) (volume $1 \mathrm{ml} / \mathrm{kg}$ ) made based on each mouse's weight and solubilized with $0.5 \mathrm{ml}$ natrium citrate at a $\mathrm{pH}$ of 4.5 before injection. ${ }^{15-16}$ The mice were given food and water 30 minutes after the injection and the plasma blood glucose level of each mouse was evaluated 72 hours, using blood drawn from the tail.

\section{Experimental design}

To determine the fasting blood glucose levels, the mice were separated into nine groups of four mice each. The plant extract were administered three days after the injection to all the groups, except the diabetes control group. Subsequently, blood samples were drawn from each group on days $0,3,9,12$, and 15 , to determine the blood glucose levels. Group 1 served as diabetic control and group 2 was administered standard drugs (glibenclamide, $5 \mathrm{mg} / \mathrm{kgBW}$ orally, daily). Also, groups $3,4,5$, and 6 were administered the ethanol extract at doses of 25, 50, 100 , and $200 \mathrm{mg} / \mathrm{kgBW}$, respectively, while groups 7,8 , and 9 received the water fraction, ethyl acetate fraction, and n-hexane fraction (100 $\mathrm{mg} / \mathrm{kgBW}$ each day) respectively, for two weeks.

\section{Data analysis}

The results are displayed as mean \pm SEM values. In addition, Oneway analysis of variance (ANOVA) was performed to determine the differences in mean values between treatment groups. Subsequently, a Tukey's test was performed to determine whether the group mean values were significantly different at $p<0.05$. Meanwhile, the data were analyzed statistically using SPSS version 22 , and converted into bar charts and tables, using Excel 2019.

\section{RESULTS AND DISCUSSION}

\section{Anti-diabetic activity of extract and fractions of $C$. costata leaves}

For two weeks, alloxan-induced diabetic mice were orally administered ethanolic extract and fractions of $C$. costata. Alloxan induces builds up through the glucose transporter 2 (GLUT2) and tends to destroy certain types of insulin secreted by pancreatic cells, resulting in decreased glucose absorption by peripheral organs, consequently, inducing diabetes. This is because alloxan induces the production of free radicals through redox processes, causing tissue damage, as well as cell degranulation, and ultimately, cell degeneration..$^{15-17}$ This was corroborated by the increased fasting blood glucose level measured 72 hours after injection.

Based on the results, there was a significant reduction in the glucose levels of blood samples from the mice treated for two weeks with $C$. costata extract and fractions. However, after 9 days of treatment, no significant changes in glucose levels were observed. In comparison to the glibenclamide $(5 \mathrm{mg} / \mathrm{kg})$ group, there were significant $(p<0.05)$ hypoglycemic effects between day 9 and day 15 . In addition, a significant $(p<0.05)$ reduction in glucose levels was observed in the blood samples from the groups treated with $C$. costata extract and fractions, from day 12 to 15 , compared to the diabetic control group. Table 1 shows the effect of various dosages of $C$. costata extract and fractions on the fasting blood glucose levels of the mice.

These findings show the extract and fractions of $C$. costata leaves have the capacity to decrease blood glucose levels in mice. The ethanolic extract of $C$. costata leaves significantly $(p<0.05)$ decreased blood glucose level in a dose-dependent manner with the inhibitory activity observed in the C. costata-treated mice at doses of $25 \mathrm{mg} / \mathrm{kgBW}$ (\% DBGL: $21.10 \pm 3.02 \%$ ), $50 \mathrm{mg} / \mathrm{kgBW}$ (\% DBGL: $46.36 \pm 3.90 \%$ ), $100 \mathrm{mg} / \mathrm{kgBW}$ (\% DBGL: $58.94 \pm 1.58 \%$ ) and $200 \mathrm{mg} / \mathrm{kgBW}$ (\% DBGL: $60.93 \pm 1.79 \%$ ). However, the water fraction of $C$. costata leaves produced a higher reduction of blood glucose level (\% DBGL: 78.93 $\pm 5.62 \%$ ), compared to the ethyl acetate fraction (\% DBGL: $67.06 \pm 1.82 \%$ ) and $n$-hexane fraction (\% DBGL: 58.83 $\pm 4.00 \%$ ) (Figure 1).

Therefore, the extract and fractions of $C$. costata leaves were concluded to be able to reduce the elevated fasting blood glucose level. This ability is possibly due to the presence of antioxidant phytochemicals, for instance, flavonoids, polyphenols, and tannins, which act as free radical scavengers. ${ }^{12,17-18}$ The antioxidants' mechanism of action is believed to be an insulin-like effect on peripheral tissues, through stimulation of the regeneration process or the release of pancreatic insulin synthesis from existing cells. This increases the rate of glucose removal from the circulation by increasing filtration, as well as renal excretion, and improving metabolism, as well as fat deposit integration, a process involving insulin synthesis by the pancreas. ${ }^{17}$

\section{CONCLUSION}

The extract and fractions of $C$. costata leaves exhibited a considerable anti-diabetic effect, as demonstrated in this study. These findings corroborate the plant's use for diabetes treatment by traditional practitioners in North Sumatra. However, further studies are required to determine the exact mechanism of the anti-diabetic effect of $C$. costata leaves. 
Table 1: Effect of extract and fractions of $C$. costata on fasting blood glucose level.

\begin{tabular}{|c|c|c|c|c|c|c|}
\hline \multirow{2}{*}{ Trial Group } & \multicolumn{6}{|c|}{ Fasting blood glucose level (mg/dl) } \\
\hline & Day 0 & Day 3 & Day 6 & Day 9 & Day 12 & Day 15 \\
\hline $\mathrm{DC}$ & $273.75 \pm 48.85$ & $274.50 \pm 64.02$ & $205.25 \pm 10.06$ & $229.25 \pm 26.10$ & $234.75 \pm 18.13$ & $249.00 \pm 12.85$ \\
\hline PC & $216.75 \pm 8.20$ & $201.75 \pm 7.09$ & $189.25 \pm 3.35$ & $170.75 \pm 6.18^{* *}$ & $124.25 \pm 4.01^{* *}$ & $106.75 \pm 4.05^{\star *}$ \\
\hline CCE 25 & $226.25 \pm 3.47$ & $221.50 \pm 2.25$ & $229.50 \pm 7.77$ & $191.50 \pm 3.38$ & $183.50 \pm 5.12^{* *}$ & $178.50 \pm 4.44^{* *}$ \\
\hline CCE 50 & $250.75 \pm 14.74$ & $219.50 \pm 1.44$ & $215.50 \pm 2.90$ & $189.25 \pm 2.95$ & $159.25 \pm 5.30^{\star \star}$ & $134.50 \pm 4.91^{\star *}$ \\
\hline CCE 100 & $250.25 \pm 9.20$ & $217.50 \pm 1.04$ & $206.00 \pm 1.73$ & $187.00 \pm 2.86$ & $148.75 \pm 4.11^{\star *}$ & $102.75 \pm 1.55^{\star *}$ \\
\hline CCE 200 & $225.25 \pm 8.71$ & $215.50 \pm 1.71$ & $192.00 \pm 2.38$ & $184.50 \pm 2.66$ & $158.75 \pm 7.73^{\star \star}$ & $88.00 \pm 0.90^{\star *}$ \\
\hline WFCC 100 & $303.75 \pm 33.64$ & $249.50 \pm 28.29$ & $221.00 \pm 10.90$ & $189.75 \pm 2.39$ & $142.75 \pm 1.60^{* *}$ & $64.00 \pm 12.25^{\star *}$ \\
\hline EAFCC 100 & $294.50 \pm 23.97$ & $261.25 \pm 18.38$ & $237.25 \pm 26.63$ & $195.75 \pm 6.92$ & $163.25 \pm 10.23^{* *}$ & $97.00 \pm 6.92^{* *}$ \\
\hline nHFCC 100 & $300.00 \pm 37.73$ & $270.25 \pm 32.39$ & $229.75 \pm 15.71$ & $202.75 \pm 12.81$ & $160.50 \pm 3.43^{\star *}$ & $123.50 \pm 6.54^{\star *}$ \\
\hline
\end{tabular}

Information:

DC = Diabetic control (PGA 1\% suspension).

PC = Positive control (glibenclamide dose $5 \mathrm{mg} / \mathrm{kgBW}$ ).

CCE 25 Administration of ethanol extract of the C. costata leaves dose $25 \mathrm{mg} / \mathrm{kgBW}$.

CCE $50=$ Administration of ethanol extract of the C. costata leaves dose $50 \mathrm{mg} / \mathrm{kgBW}$.

CCE $100=$ Administration of ethanol extract of the C. costata leaves dose $100 \mathrm{mg} / \mathrm{kgBW}$.

CCE 200 = Administration of ethanol extract of the C. costata leaves dose $200 \mathrm{mg} / \mathrm{kgBW}$.

WFCC $100=$ Administration of water fraction of the $C$. costata leaves dose $100 \mathrm{mg} / \mathrm{kgBW}$.

EAFCC $100=$ Administration of ethyl acetate fraction of the C. costata leaves dose $100 \mathrm{mg} / \mathrm{kgBW}$.

nHFCC $100=$ Administration of $\mathrm{n}$-hexane fraction of the $C$. costata leaves dose $100 \mathrm{mg} / \mathrm{kgBW}$.

Data are presented as mean \pm SEM of four animals in each group. ${ }^{* *}$ shows $p<0.05$ compared to the diabetic control group. PGA: Pulvis Gummi Arabicum.

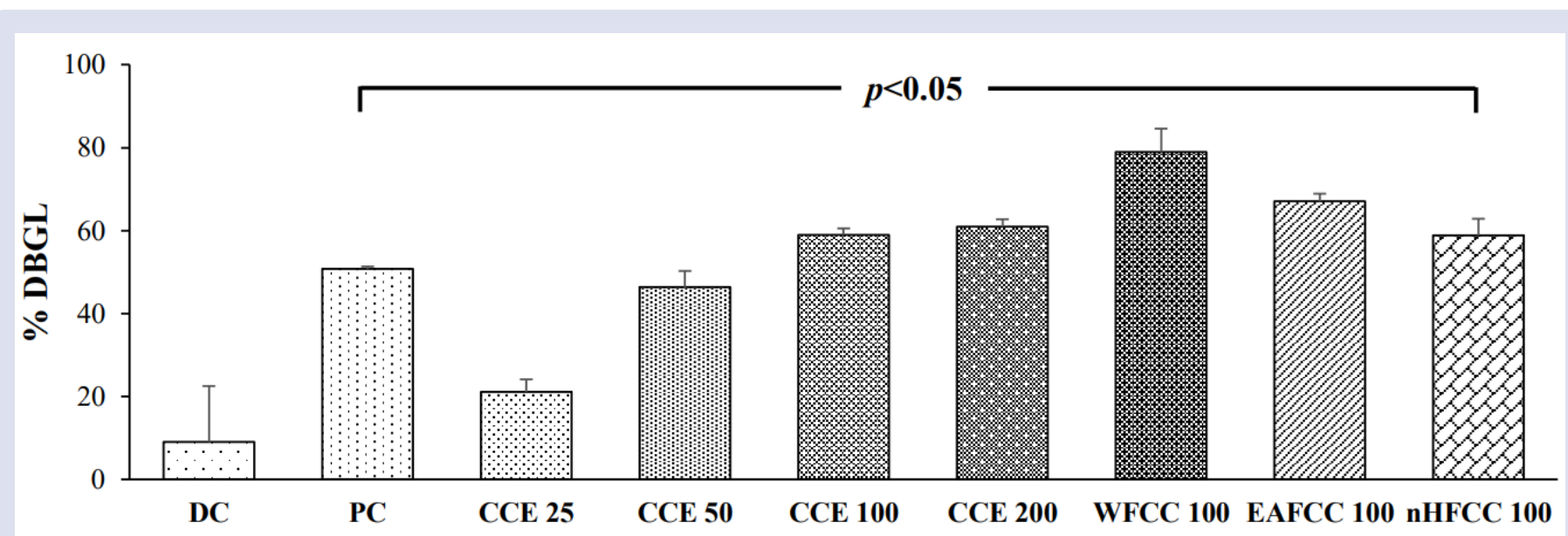

Figure 1: \% Decrease of blood glucose level (\% DBGL) of extract and fractions of C. costata. DC: Diabetic control (PGA 1\% suspension). PC: Positive control (glibenclamide dose $5 \mathrm{mg} / \mathrm{kgBW}$ ). CCE 25: Ethanol extract of the $C$. costata leaves dose $25 \mathrm{mg} / \mathrm{kgBW}$. CCE 50: Ethanol extract of the C. costata leaves dose $50 \mathrm{mg} / \mathrm{kgBW}$. CCE 100: Ethanol extract of the C. costata leaves dose $100 \mathrm{mg} / \mathrm{kgBW}$. CCE 200: Ethanol extract of the C. costata leaves dose $200 \mathrm{mg} / \mathrm{kgBW}$. WFCC 100: Water fraction of the C. costata leaves dose $100 \mathrm{mg} / \mathrm{kgBW}$. EAFCC 100: Ethyl acetate fraction of the C. costata leaves dose $100 \mathrm{mg} / \mathrm{kgBW}$. nHFCC 100: $n$-Hexane fraction of the C. costata leaves dose $100 \mathrm{mg} / \mathrm{kgBW}$. Data are presented as mean \pm SEM of four animals in each group. $p<0.05$ compared to the diabetic control group.

\section{REFERENCES}

1. Barcelo A, Rajpathak S. Incidence and prevalence of diabetes mellitus in the Americas. Pan Am J Public Health. 2001;10(5):300-8.

2. Tafesse TB, Hymete A, Mekonnen Y, Tadesse M. Antidiabetic activity and phytochemical screening of extracts of the leaves of Ajuga remota Benth on alloxan-induced diabetic mice. BMC Complement Altern Med. 2017;17(243):1-9.

3. Ogurtsova K, da Rocha Fernandes JD, Huang Y, Linnenkamp U, Guariguata L, Cho NH, et al. IDF diabetes atlas: global estimates for the prevalence of diabetes for 2015 and 2040. Diabetes Res Clin Pract. 2017;128:40-50.

4. Piero MN, Nzaro GM, Njagi JM. Diabetes mellitus-a devastating metabolic disorder. Asian J Biomed Pharm Sci. 2015;5(40):1-7.

5. Bastaki A. Diabetes mellitus and its treatment. Int J Diabetes Metab. 2005;13(3):111-34
6. Sakthiswary R, Zakaria Z, Das S. Diabetes mellitus: treatment challenges and the role of some herbal therapies. Middle East J Sci Res. 2014;20(7):786-98.

7. Mollica A, Zengin G, Locatelli M, Stefanucci A, Macedonio G Bellagamba $G$, et al. An assessment of the nutraceutical potential of Juglans regia $L$. leaf powder in diabetic rats. Food and Chem Toxicol. 2017; 107:554-64.

8. Stefanucci A, Zengin G, Locatelli M, Macedonio G, Wang CK, Novellino $E$, et al. Impact of different geographical locations on varying profile of bioactive and associated functionalities of caper (Capparis spinosa L.). Food Chem Toxicol. 2018;118:181-89.

9. Elfahmi, Woerdenbag HJ, Kayser O. Jamu: Indonesian traditional herbal medicine towards rational phytopharmacological use. J Herb Med. 2014;4:51-73.

10. Alkandahri MY, Berbudi A, Utami NV, Subarnas A. Antimalarial activity of extract and fractions of Castanopsis costata (Blume) A.DC. Avicenna J Phytomed. 2019;9(5):474-81. 
11. Salim E, Fatimah C, Fanny DY. Analgetic activity of Cep-cepan (Saurauia cauliflora Dc.) leaves extract. J Nat. 2017;17(1):31-38.

12. Alkandahri MY, Nisriadi L, Salim E. Secondary metabolites and antioxidant activity of methanol extract of Castanopsis costata Leaves. Pharmacol Clin Pharm Res. 2016;1(3):98-102.

13. Alkandahri MY, Siahaan PN, Salim E, Fatimah C. Anti-inflammatory activity of Cep-cepan leaves (Castanopsis costata (Blume) A.DC). Int J Curr Med Sci. 2018;8(4):424-29.

14. Gidado A, Ameh DA, Atawodi SE. Effect of Nauclea latifolia leaves aqueous extracts on blood glucose levels of normal and alloxaninduced diabetic rats. Afr J Biotechnol. 2005:4(1):91-93.
15. Carvalho EN, Carvalho NAS, Ferreira LM. Experimental model of induction of diabetes mellitus in rats. Acta Cir Bras. 2003;18:60-64.

16. Kamalakkanan N, Prince PSM. Hypoglycemic effect of water extracts of Aegle marmelos fruits in streptozotocin-diabetic rats. $J$ Ethnopharmacol. 2003;87(2-3):207-10.

17. Muhtadi, Primarianti AU, Sujono TA. Antidiabetic activity of Durian (Durio zibethinus Murr.) and Rambutan (Nephelium lappaceum L.) fruit peels in alloxan diabetic rats. Procedia Food Sci. 2015;3:255-61.

18. Sharma B, Balomajumder C, Roy P. Hypoglycemic and hypolipidemic effects of flavonoid rich extract from Eugenia jambolana seeds on streptozotocin induced diabetic rats. Food Chem Toxicol. 2008:46:2376-83

\section{GRAPHICAL ABSTRACT}
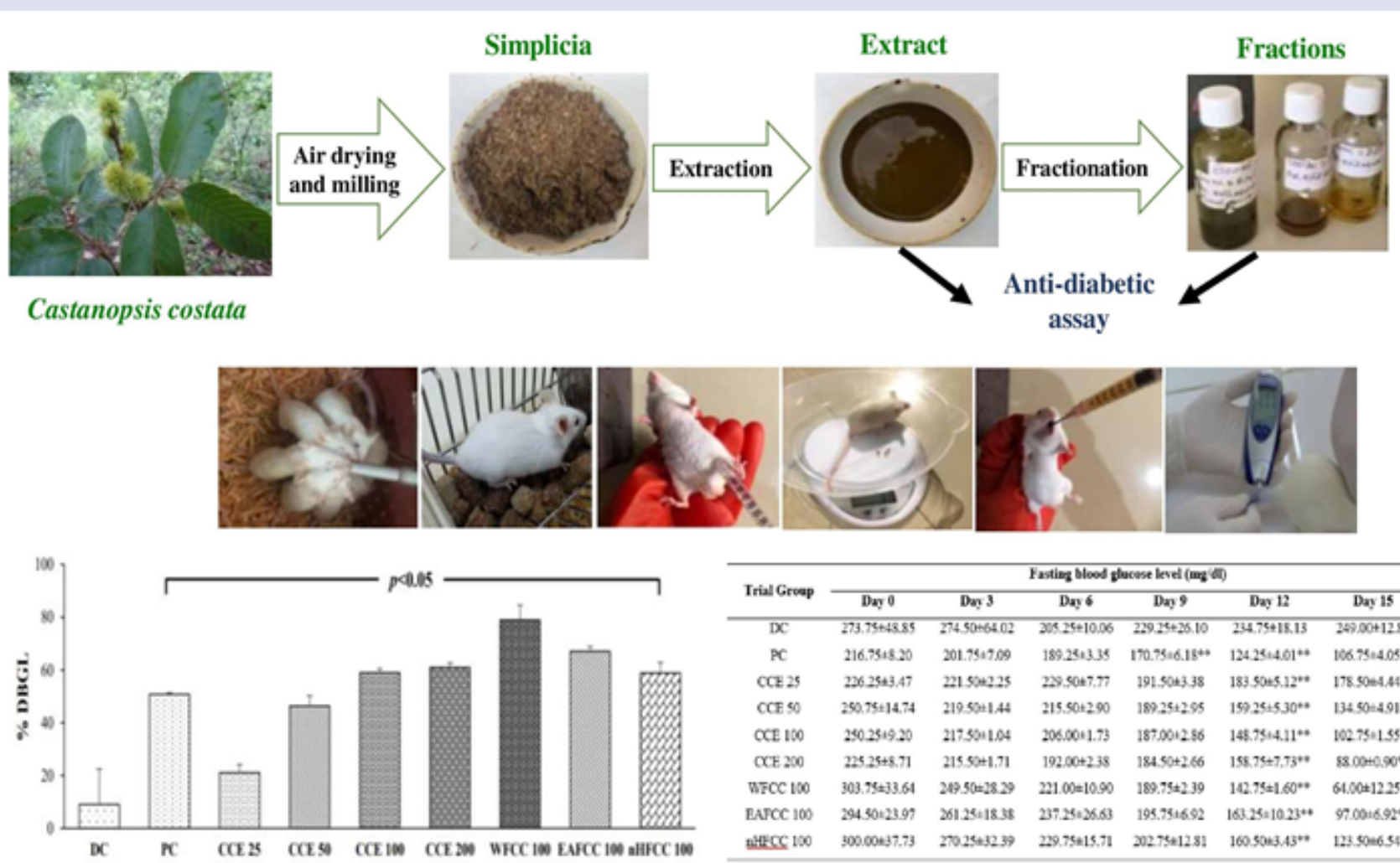

\begin{tabular}{|c|c|c|c|c|c|c|}
\hline \multirow{2}{*}{ Trial Growp } & \multicolumn{6}{|c|}{ 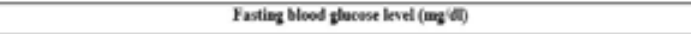 } \\
\hline & Day 0 & Dos 3 & Day 6 & Don 9 & $D x y 12$ & Day 15 \\
\hline $\mathrm{DC}$ & $273.73+43.85$ & $27450+6402$ & $205.24+10.06$ & $229.24+25.10$ & $234.75+18.13$ & $259.90+12.8$ \\
\hline PC & $216.75 \div 5: 20$ & 201.7547 .09 & $189.25+3.35$ & $170.75=6.18+4$ & 12428440100 & $106.85=4.054 *$ \\
\hline CCE $2 s$ & $20625 \div 3,47$ & 21.504225 & $28.5047,77$ & $191.50+3,38$ & $183.5045 .12^{* *}$ & $178.50=4,4^{* *}$ \\
\hline CCF 50 & $250.75 \div 14.74$ & $210.50+1,44$ & $215.50+290$ & $180.25+2.55$ & $159.25+530^{* *}$ & $13450=491^{* 4}$ \\
\hline CEE 100 & 250.2519 .20 & 2175041,04 & $206.00 \div 1.73$ & 187.0012 .56 & $145.754 .4 .11^{* *}$ & $10275=1.55 * 4$ \\
\hline CCE 200 & $25.25+5.71$ & $215.50+1.71$ & $192.00+2.38$ & $184.60+266$ & $158.75+7.73^{* 4}$ & $5800+0.90^{* *}$ \\
\hline wrec to & $303.7 \times \pm 33.64$ & $249.50=28.29$ & $22.00=10.90$ & $189.75 \times 2.39$ & $142.75 \pm 1.60^{* * *}$ & $64.00 \pm 12.25 * 4$ \\
\hline EAPCC 100 & $29450 \div 23.97$ & $261.28 \div 18.38$ & $237.25=26.63$ & $195.79+692$ & $163.25=10.23 * 4$ & $9700016.92 *$ \\
\hline AHECC 100 & $300.00 \times 37,73$ & $270.25 * 32.39$ & $229.75 * 15.71$ & $2027 * 4281$ & $160.50 \pm 3,43^{* *}$ & $123.50=654^{\circ}$ \\
\hline
\end{tabular}

\section{ABOUT AUTHORS}

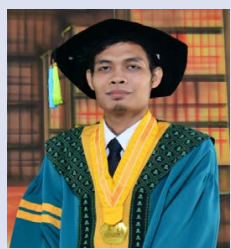

Maulana Yusuf Alkandahri: $\mathrm{He}$ is a pharmacist, lecturer and researcher at the Faculty of Pharmacy, Buana Perjuangan Karawang University, Karawang, West Java, Indonesia. He is completed Master of Pharmacology from the Faculty of Pharmacy, Padjadjaran University, Bandung, West Java, Indonesia in 2018, after which he is continued his Ph.D program at the Department of Pharmacology and Clinical Pharmacy, Faculty of Pharmacy, Padjadjaran University. Currently, he is focused on conducting research on local Indonesian medicinal plants that have pharmacological activity.

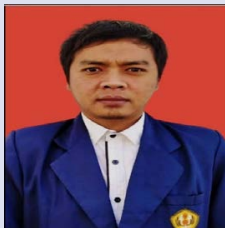

Dani Sujana: He is a pharmacist, lecturer and researcher at the Diploma Program of Pharmacy, Karsa Husada Garut College of Health Sciences, Garut, West Java, Indonesia. He is completed Master of Pharmacology from the Faculty of Pharmacy, Padjadjaran University, Bandung, West Java, Indonesia in 2019, after which he is continued his Ph.D program at the Department of Pharmacology and Clinical Pharmacy, Faculty of Pharmacy, Padjadjaran University. Research interests are pharmacological activity, especially from natural product. 

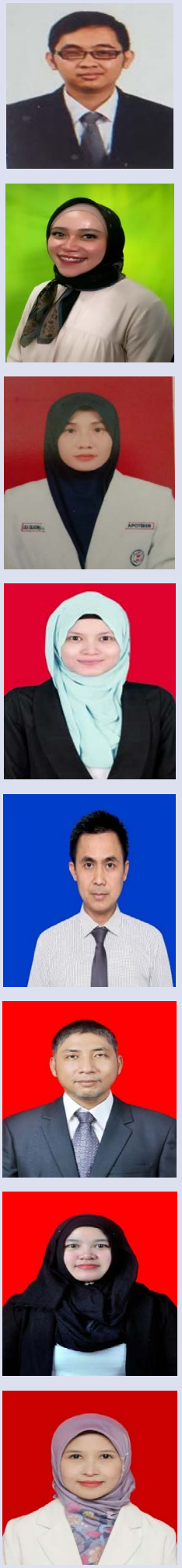

Dadang Muhammad Hasyim: He is a lecturer and researcher at the Diploma Program of Pharmacy, Karsa Husada Garut College of Health Sciences, Garut, West Java, Indonesia. He is completed Master of Chemistry from Graduate School, IPB University, Bogor, West Java, Indonesia in 2011, after which he is continued his Ph.D program at the Department of Pharmaceutical Analysis and Medicinal Chemistry, Faculty of Pharmacy, Padjadjaran University. Research interests are natural products chemistry and pharmaceutical analysis.

Mareetha Zahra Shafirany: She is a pharmacist, lecturer and researcher at the Department of Pharmaceutical Biology, School of Pharmacy Muhammadiyah Cirebon, Cirebon, West Java, Indonesia. She is completed Master of Pharmaceutical Biology from the Faculty of Pharmacy, Padjadjaran University, Bandung, West Java, Indonesia. Her research is focusing on pharmacological activity studies of Rosella plants (Hibiscus sabdariffa L).

Lela Sulastri: She is a pharmacist, lecturer and researcher at the Department of Pharmaceutics and Pharmaceutical Technology, School of Pharmacy Muhammadiyah Cirebon, Cirebon, West Java, Indonesia. She is completed Master of Pharmaceutics and Pharmaceutical Technology from the Faculty of Pharmacy, Pancasila University, Jakarta, Indonesia. Her research is focusing on formulation and hair growth activity of a combination of Green Tea (Camellia sinensis L.) and Gotu Kola (Centella asiatica (L.) Urban.) herb water.

Maya Arfania: She is a pharmacist, lecturer and researcher at the Faculty of Pharmacy, Buana Perjuangan Karawang University, Karawang, West Java, Indonesia. She is completed Master of Clinical Pharmacy from the Faculty of Pharmacy, Gadjah Mada University, Yogyakarta, Indonesia. Her research is focusing on potential drug interactions in patients with diabetes mellitus.

Dedy Frianto: He is a pharmacist, lecturer and researcher at the Faculty of Pharmacy, Buana Perjuangan Karawang University, Karawang, West Java, Indonesia. He is completed Master of Management from the Faculty of Economics, Pasundan University, Bandung, West Java, Indonesia in 2014, after which he is continued his Ph.D program at the Department of Pharmacology and Clinical Pharmacy, Faculty of Pharmacy, Padjadjaran University. Currently, he is focused on conducting research about pharmacoeconomics, pharmacoepidemiology and health insurance on local Indonesian.

Farhamzah: He is a lecturer and researcher at the Faculty of Pharmacy, Buana Perjuangan Karawang University, Karawang, West Java, Indonesia. He is completed Master of Information Technology from the Faculty of Science and Technology, Raharja University, Tangerang, Banten, Indonesia in 2019. Currently, he is focused on conducting research about formulation and physical evaluation of Beluntas plants (Pluchea indica (L.) Less).

Anggun Hari Kusumawati: She is pharmacist, lecturer and researcher at the Faculty of Pharmacy, Buana Perjuangan Karawang University, Karawang, West Java, Indonesia. She is completed Master of Pharmacology and Clinical Pharmacy from the School of Pharmacy, Bandung Institute of Technology, Bandung, West Java, Indonesia in 2016, after which she is continued his Ph.D program at the Department of Pharmaceutica, School of Pharmacy, Bandung Institute of Technology. Her research is focusing on nanotechnology of Black Rice (Oryza sativa var. glutinosa) extracts for nutraceutical products.

Nia Yuniarsih: She is a pharmacist, lecturer and researcher at the Faculty of Pharmacy, Buana Perjuangan Karawang University, Karawang, West Java, Indonesia. She is completed Master of Pharmaceutics and Pharmaceutical Technology from the Faculty of Pharmacy, Padjadjaran University. Her research is focusing on formulation and physical evaluation of Kepok Banana (Musa paradisiaca L). 